\title{
The Influence of the Use of Focusky Application Based on Presentation Media on Student Learning Outcomes in Indonesian Language Subject at Junior High School Luwu District
}

\author{
Rahmawati $^{1 *}$, Pujiyanti Fauziah ${ }^{2}$, and Ferry Setiawan ${ }^{3}$ \\ ${ }^{1,2)}$ Non Formal Education, Graduate School, Yogyakarta State University, Indonesia \\ ${ }^{3)}$ Education Technology, Makassar State University, Indonesia \\ *rahmasahidin10@gmail.com
}

\begin{abstract}
The purpose of this study was to find out the description of student learning outcomes in Indonesian 8th grade subjects in SMP 3 Belopa (Junior High School) using Focusky presentation media and to determine the effect of using media percentage on student learning outcomes. The approach used is a quantitative approach with an experimental method. The population of this study was all students totaling 117 students. The samples in this study were class 8.1 and 8.2. Based on the learning outcomes in grades 8.1 and 8.2 , both classes have the same number of students and obtain an almost equal learning average. Class random sampling. Data collection using observation, tests, and documentation. This research uses descriptive analysis techniques and inferential statistical analysis. The results of this study indicate a significance there is an influence of student learning outcomes by using Focusky presentation media on Indonesian language subjects.
\end{abstract}

Keywords: focusky application, media, Indonesia language subject

\section{Introduction}

Learning media is one component that cannot be taken from the learning process. Supporting learning media can be one of the successes of the learning process. Learning media is a separate arrangement of material to create an environment or interaction that allows students to learn. Because of the importance of using instructional media, it is appropriate that the media be considered as a channel of messages or information from the teacher to students, not just making media as a tool that helps the learning process.

Learning Media aims to facilitate the learning process. In this process the teacher must be able to align learning media with learning methods. Learning media according to Derek Rowntree [1]: (a) arousing learning motivation, (b) repeating what has been learned, (c) providing learning stimulus, (d) activating student responses, (e) provide immediate feedback, (f) promote harmonious training. Based on the results of preliminary observations in SMP Negeri 3 Belopa (Junior High School) in the learning process are still fully guided by the teacher, for example the teacher explains step by step each process, if not guided by the teacher students often not doing all the stages of the process that should have been done or not quite right in taking steps. In SMP Negeri 3 Belopa there are no learning media that can attract learners' motivation in taking Indonesian Language subjects. Learning media in the form of a percentage can visualize learning theory in SMP Negeri 3 Belopa, Luwu Regency. 
Indonesian Language Learning [2] directed to improve the ability of students to communicate in Indonesian properly and correctly, both verbally and in writing, as well as developing critical and creative thinking skills. Indonesian language activities include productive and receptive activities in four aspects of language, namely listening, speaking, reading and writing.

An interesting learning atmosphere and will affect students' interest and motivation to learn [3]. The use of instructional media in the teaching and learning process can arouse new desires and interests, generate motivation and stimulation of learning activities, and even bring psychological influences on students. Innovative learning media based on information and communication technology, one of which is Focusky is a presentation media that provides many interesting and unique features that can attract students' attention. This study aims to know the description of student learning outcomes in Indonesian Language especially at Class 8th by applying Focusky Presentation Media and the effect on student learning outcomes in Indonesian Language Subject.

Learning is a change in behavior in an individual due to the interaction between individuals and individuals and the environment [4]. Learning is a process of behavior change that occurs in a person, which is obtained in terms of experience in a reinforced environment. [5] defines instructional media to show various components of the learning environment that can cause stimulants for students (students), which causes communication with students, including in this sense teachers, objects (objects), various kinds of equipment ranging from books to television which generally have the function of providing input to students. In the development of technology now various kinds of media can be used in the learning process, indirectly requiring teachers to be able to understand and choose the right media to be used in each learning material [4]. Learning consists of print, audio, visual and audiovisual media and also learning media in the form of two-dimensional and three-dimensional media. The most important thing in learning media is the delivery of a message or information to the recipient.

Presentation is a form of exposure of information, objects, tools, ideas or ideas, and new findings to other people or groups so that what is presented can be seen, understood, observed and examined by people who pay attention or the audience. The use of multimedia is very helpful for teachers in the learning process because multimedia can make the learning process more interesting and innovative. Multimedia can change all media elements in the form of audio, video, images, text, etc. into one and look more attractive especially combined with a variety of colors in line with the object, making the teaching material to be delivered more innovative and more interesting, from non-multimedia learning that seems boring to students.

Focusky is one of the new generation presentation applications that overturns almost all ideas held about presentations. Focusky can improve work efficiency, because the built-in screen recorder can help record screen activity, it can also be used directly to create video material and install third-party screen recorders. In addition, Focusky can convey complex information to the audience simply and visually. Making a Focusky presentation can help enrich presentations with multimedia content. That is, shapes, text, images, links, videos, music and flash can be easily incorporated into presentations. Compared to single text presentations, it can present content in various media ways that ensure that the presentation is fun to watch. Focusky provides a lot of pre-designed and professional video backgrounds to enhance your presentations. Background video is a good way to attract the attention of students. Simply apply the default video background and make students have an extraordinary visual presentation experience. The advantages of Focusky are that it's easy to create new presentations, beautiful and varied templates, online and online, amazing Zooming Effects, animation effects and transition effects, infinite canvas and unlimited zoom and pan effects, 
realistic 3D backgrounds, background images and backgrounds video easily change background color, easy in drag and drop frames for canvas, preview presentation immediately when editing save project only for later reediting, quickly save current settings as templates. As for Focusky's lack of reference books related to Focusky media, not everyone can use this application, because to have it the user must first download Focusky software to be able to use the facilities contained in the Focusky user application or the user must upgrade the Focusky software, Become a pro and it is not free or paid in the process of storing the results of presentations made in offline mode to save to publish them first.

Learning Indonesian by using Focusky's presentation media can be guided by the general steps of learning in direct learning. Where the Indonesian Language Subjects using Focusky presentation media belong to the teacher-centered direct learning model (teacher-centered learning). Direct learning is a learning model that is actually teacher centered. In applying the direct learning model, the teacher must demonstrate the knowledge or skills that will be trained on students step by step. Direct learning requires the activeness, expertise, skills and creativity of the teacher without eliminating the role of students as student subjects.

The steps for learning Indonesian by using Focusky-based presentation media are as follows (a) Learning Preparation, (b) Presentation of Material and (3) Closing Activities. Learning outcomes are the abilities, attitudes, and skills of students which can be shown by the value given by the teacher after providing subject matter. Therefore, learning outcomes have an important role in the learning process because it will provide an information to teachers about the progress of students in efforts to achieve learning objectives. The factors that influence learning outcomes can be classified into two namely as follows (1) Internal factors; internal factors are factors that originate from within students that affect their learning abilities including intelligence, interest and attention, motivation to learn, perseverance, as well as physical and health conditions. (2) External factors, originating from outside the student's self that affect learning outcomes are family, school, and society.

\section{Research Method}

The implementation of this research is a quantitative approach. The quantitative approach was chosen because the research data obtained were in the form of numbers and analyzed using statistics with the aim of testing the hypotheses that had been set previously. The research used in this study is an experiment, because, experimental research is closely related in testing a hypothesis in order to look for influence, relationships, and differences in changes to the groups subject to treatment. The approach and type of the study were chosen to compare the level of student learning outcomes before and after being given treatment in the form of learning by using focusky presentation media on student learning outcomes at $8^{\text {th }}$ grade SMP Negeri 3 Belopa, Luwu Regency in Indonesian Launguage Subject. The research design used is the Posttest Only Control Group design [3]. In general, the research design that will be used can be described as follows:

Table 3.1. Posttest Only Control Group Design

\begin{tabular}{lcl}
\hline Group & Dependent variable & Posttest \\
\hline Experiment & $\mathrm{X}_{1}$ & $\mathrm{O}_{2}$ \\
Control & $\mathrm{X}_{2}$ & $\mathrm{O}_{2}$ \\
\hline
\end{tabular}

Note: $\quad \mathrm{X} 1=$ Treatment in the Focusky experimental class

$\mathrm{X} 2$ = Treatment of the Power Point control class

$\mathrm{O} 2=$ Posttest 
This study consists of two variables, namely the independent variable and the dependent variable. The independent variable referred to in this study is the use of Focusky-based presentation media (the influencing variable), while the dependent variable is student learning outcomes in Indonesian language learning (the affected variable). The two research variables are used to obtain the limitations used to avoid differences in interpretation of the variables studied and at the same time the perception of the variables being studied.

Operational definition To avoid misinterpretation of changes in this study, the researcher clarifies the operational definition of the intended change: The use of Focusky-based presentation media in this study is as a medium in the learning process during the study period. Where the results of this presentation media which later will be a complete unit consisting of a series of materials and learning activities arranged to help students achieve a number of objectives that are specifically and clearly formulated in the form of presentations.

Learning outcomes are test scores obtained by students after being taught using Focuskybased presentation media in the experimental class and student test results after being taught without using Focusky-based presentation media in the control class obtained from learning outcomes tests on Indonesian Language Subjects at the end of the meeting. The population and sample in this study were all students of class $8^{\text {th }}$ SMP Negeri 3 Belopa as 117 people consisting of 5 classes. The sampling technique in this study was class 8th.1 and bth.2, and both of them get almost the same average results, number of students and average of age.

Observations were carried out before and during the study. Observations carried out before the study aimed to obtain preliminary data in the form of school environment conditions, the characteristics of teachers in this case the teacher, the characteristics of students or students, as well as the learning tools contained in the school. Meanwhile, the observations carried out at the time of the research aimed at obtaining data in the form of teacher activities in the classroom while carrying out the Indonesian learning process, teacher activities using Focusky-based presentation media, student activities following learning using Focusky-based presentation media, as well as supporting and inhibiting factors found during learning. Inferential statistical analysis is intended to test hypotheses using t-test that is to find out whether there are differences in the abilities of students taught by using Focusky-based presentation media in the experimental class.

\section{Results and Discussion}

This study consisted of two classes that were given different treatments to describe the implementation of learning by using Focusky in class $8^{\text {th }} .1$ as experimental class and knowing the effect of student learning outcomes with students taught using Power Point in class bth.2 as control class in Indonesian Language Subjects. Teaching and learning process carried out in two classes with the aim to compare the implementation of learning that uses Focusky with the implementation of learning using Power Point. This research was conducted during three meetings and obtained a description of the results of research through observations of teacher activities and observations of student activities in earnest, then at the end of the meeting each sample class was given a posttest question which also intends to obtain student learning outcomes data.

Observation Results of Teacher Activities in the Learning Process Based on the results of the analysis it can be concluded that at the first meeting the learning process carried out obtained a level of achievement with a percentage of $69.23 \%$ with a score of 9 out of 13 items in the effective category. At the second meeting the learning process carried out obtained a level of achievement with a percentage of $84.62 \%$ with the acquisition score of 11 of 13 items 
in the effective category. At the third meeting the learning process carried out obtained a level of achievement with a percentage of $92.31 \%$ with the acquisition score of 12 out of 13 items in the very effective category.

Recapitulation of the results of observations of teacher activities in the use of Focusky in learning Indonesian can be seen in the table 1.

Table 1. Observed Aspect of Teacher Activities

\begin{tabular}{llcccccc}
\hline \multirow{2}{*}{ No } & \multirow{2}{*}{ Observed aspects } & \multicolumn{2}{c}{ Meeting I } & \multicolumn{2}{c}{ Meeting II } & \multicolumn{2}{c}{ Meeting III } \\
\cline { 3 - 8 } & & Yes & No & Yes & No & Yes & No \\
\cline { 2 - 8 } & & $\mathbf{1}$ & $\mathbf{0}$ & $\mathbf{1}$ & $\mathbf{0}$ & $\mathbf{1}$ & $\mathbf{0}$ \\
\hline 1 & Objective conditions & 9 & 4 & 11 & 2 & 12 & 1 \\
\hline 2 & Maximum score & \multicolumn{2}{c}{13} & & 13 & \multicolumn{2}{c}{13} \\
\hline 3 & Achievement score & \multicolumn{2}{c}{9} & & 11 & \multicolumn{2}{c}{12} \\
\hline 4 & Percentage of & & \multicolumn{2}{c}{$84,62 \%$} & \multicolumn{2}{c}{$92,31 \%$} \\
\hline
\end{tabular}

Observation Results of Student Activities in the Learning Process at the first meeting the learning process carried out obtained a level of achievement with a percentage of $73.80 \%$ in the effective category. In the second meeting the learning process carried out obtained a level of achievement with a percentage of $86.19 \%$ which is in the effective category. At the third meeting the learning process carried out obtained a level of achievement with a percentage of $92.38 \%$ in the very effective category. Recapitulation of the results of observations of student activities in the use of Focusky in learning Indonesian can be seen in the table (Table 4.2)

Table 2. Observed Aspect of Student Activities

\begin{tabular}{|c|c|c|c|c|c|c|c|}
\hline \multirow{3}{*}{ No } & \multirow{3}{*}{ Observed aspects } & \multicolumn{2}{|c|}{ Meeting I } & \multicolumn{2}{|c|}{ Meeting II } & \multicolumn{2}{|c|}{ Meeting III } \\
\hline & & Yes & No & Yes & No & Yes & No \\
\hline & & 1 & 0 & 1 & 0 & 1 & 0 \\
\hline 1 & Objective conditions & 155 & 55 & 181 & 29 & 194 & 16 \\
\hline 2 & Maximum score & \multicolumn{2}{|c|}{210} & \multicolumn{2}{|c|}{210} & \multicolumn{2}{|c|}{210} \\
\hline 3 & Achievement score & \multicolumn{2}{|c|}{155} & \multicolumn{2}{|c|}{181} & \multicolumn{2}{|c|}{194} \\
\hline 4 & $\begin{array}{l}\text { Percentage of } \\
\text { achievement level }\end{array}$ & \multicolumn{2}{|c|}{$73,80 \%$} & \multicolumn{2}{|c|}{$86,19 \%$} & \multicolumn{2}{|c|}{$92,38 \%$} \\
\hline
\end{tabular}

\section{Descriptive Statistical Analysis}

Descriptive statistical data analysis was used to obtain a picture of student learning outcomes in Indonesian Language Subjects, both the experimental class using Focusky and the control class using Power Point media. in the experimental class the lowest value is 75 which is the minimum value and the highest value is 100 which is the maximum value, with an average value of 87.619 and a standard deviation of 3.17815. Whereas in the control class, the lowest value is 70 which is the minimum value and the highest value is 90 which is the maximum value, with an average value of 79.761 and a standard deviation of 2.32565 . For more details, pay attention to the following table. 
Table 3. Descriptive Statistics of Student Learning Outcomes

\begin{tabular}{lcc}
\hline Statistics & \multicolumn{2}{c}{ Statistical Value } \\
\cline { 2 - 3 } & Experimental Class & Control Class \\
\hline Number of Samples & 21 & 21 \\
Lowest Value & 75 & 70 \\
The highest score & 100 & 90 \\
Average value & 87.619 & 79,761 \\
Standard Deviation & 3.178 & 2,325 \\
\hline
\end{tabular}

If student learning outcomes are grouped into categories of very less, less, enough, good, and very good, frequency and percentage will be obtained. And the following table is the frequency distribution and percentage of learning outcomes in Indonesian Language Subjects in class VIII SMP Negeri 3 Belopa, Luwu Regency.

Table 4. Score Classification, Frequency Distribution and Percentage of Posttest Results Experiment Class and Control Class

\begin{tabular}{llccccc}
\hline Score & Category & Value of & \multicolumn{2}{c}{ Experiment Class } & \multicolumn{2}{c}{ Control class } \\
& & letters & Frequency & Percentage & Frequency & Percentage \\
\hline $80-100$ & Very well & A & 19 & $90,47 \%$ & 15 & $71,42 \%$ \\
$66-79$ & Well & B & 2 & $9,52 \%$ & 6 & $28,57 \%$ \\
$56-65$ & Enough & C & 0 & $0 \%$ & 0 & $0 \%$ \\
$46-55$ & Less & D & 0 & $0 \%$ & 0 & $0 \%$ \\
$0-45$ & Very less & E & 0 & $0 \%$ & 0 & $0 \%$ \\
Amount & & & 21 & $100 \%$ & 21 & $100 \%$ \\
\hline
\end{tabular}

Based on the above table, it can be concluded that the learning outcomes of Indonesian Language Subjects students after the posttest in the experimental group and the control class are:

1) The results of the Experiment group posttest namely: There are no students in the category of "Very Less" with the classification of values in the letter E, there are no students who are in the category of "Less" with the classification of values in the letter D, there are no students who are in the in the category of "Enough" with the classification of values in letters namely C, 2 students $(9.52 \%)$ who are in the category of "Good" with the classification of values in letters that are B, 19 students $(90.47 \%)$ who are in the category of "Good Once "with the classification of values in letters, namely A.

2) The results of the control group posttest namely: There are no students who are in the category of "Very Less" with the classification of values in the letter E, no students who are in the category of "Less" with the classification of values in the letter D, there are no students who are in the category in the category of "Enough" with the classification of values in letters namely C, 6 students $(28.57 \%)$ who are in the category of "Good" with the classification of values in letters namely B, 15 students $(71.42 \%)$ who are in the category of "Good Once "with the classification of values in letters, namely A.

In the conclusion above, it can be seen that the results of the experimental class posttest have more students who are in the category of "Very Good" than in the control class. So that 
students in the experimental class who applied the treatment in the form of using Focusky got very good learning outcomes compared to students in the control class who used Focusky. Inferential Statistical Analysis Data obtained from this study in the form of test results (posttest) will be processed using statistical formulas, after getting the results of the statistical data analysis, then hypothesis testing is held to obtain answers from this research.

Table 5. Inferential Data Analysis of Experiment Class and Control Class

\begin{tabular}{lcc}
\hline Data analysis & $\mathrm{X}$ & $\mathrm{Y}$ \\
\hline Mean (M) & 87,619 & 79,761 \\
Standard Deviation Of Squares & 63,563 & 46,516 \\
Standard Deviation of Mean Squares & 3,17815 & 2,32565 \\
SDbm & & 2,34601 \\
t-test & \multicolumn{2}{c}{3,34951} \\
d.b. & \multicolumn{2}{c}{40} \\
\hline
\end{tabular}

The variable $\mathrm{X}$ in the table above is the experimental class while the $\mathrm{Y}$ variable is the control class, from the table above it can be seen that the average value of the experimental class is greater than the control class, but the size of the value cannot answer the research question before testing the hypothesis. Therefore, it is necessary to know the value of the table of the degree of freedom obtained is 40 , at a significant level of $5 \%$ or if it is minimized is 0.05 then a table of 1.68385 is obtained, then hypothesis testing will be held.

Based on the results of data processing obtained $t$ count of 3.34951 while the value of $t$ table with $\mathrm{db}=40$ at a significant level of $5 \%$ obtained the value of $t$ table of 1.683 . The value of $t_{\text {count }}>t_{\text {table }}(3.349>1.683)$ then there is significant influence of the use of Focusky on student learning outcomes in Indonesian Language. Based on the results of observation and posttest in the experimental class student learning outcomes are higher than the control class. The results of the use of Focusky are the conclusions of an increase in student learning outcomes.

\section{Conclusion}

Based on the formulation of the problem, the results of research and discussion, the results of this study can be concluded that: The description of students in the experimental class who apply treatment in the form of using Focusky media has excellent learning outcomes compared to students in the control class who do not use Focusky media. Students in the experimental class are more active in participating in learning activities due to students' interest in Focusky media that looks interesting and innovative. And there is an influence of the use of Focusky on student learning outcomes in the Indonesian Language Class VIII in SMP Negeri 3 Belopa can be seen from the results of student learning has increased to very good

Based on the results obtained, the researcher provides suggestions for various parties. First, the Principal can facilitate learning and prepare learning needs, especially in providing learning media to help the learning process become better in its implementation. For teachers or educators to consider and apply the use media, especially computer-based media in the learning process so that learning becomes more effective and enjoyable, For students to be 
more active and enthusiastic in learning by using interactive media at school. And for researchers to be further reference material in developing research in the future.

\section{References}

[1] Karim H and Ahmad, A. (2007), Media Pembelajaran. Makassar:Badan Penerbit UNM.

[2] Anm. (2017), Karakteristik Pembelajaran. Retreive from : http://www.rijal09.wordpress. /2016/03/karakteristik-pembelajaran-bahasa.html

[3] Sudijono, Anas. (2013), Pengantar Evaluasi Pendidikan. Jakarta: PT RajaGrafindo Persada.

[4] Aunurrahman. (2011), Belajar dan Pembelajaran. Bandung: Alfabeta.

[5] Arsyad, Azhar. (2013), Media Pembelajaran (16 ${ }^{\text {th }}$-Eds). Jakarta: PT Raja Grafindo Persada.

[6] Emzir. (2014), Metodologi Penelitian Pendidikan. Jakarta : PT.Raja GrafindoPersada. 